\title{
3. The interpretation of Aboriginal 'property' on the Australian colonial frontier
}

\author{
IAN KEEN
}

\section{Prologue}

Captain Collet Barker took command of Fort Wellington garrison outpost at Raffles Bay in the Northern Territory in August 1828 and, after it was abandoned a year later, he commanded the garrison at King George Sound in the south-west of Western Australia, where he remained until the end of March 1831. He has been described as one of the more enlightened of the British officers in his dealings with Aboriginal people (Mulvaney and Green 1992:42). Relations between personnel of these outposts and local Aboriginal people have been described as amicable, and that is the impression one gets from Barker's journals. These record a variety of kinds of interaction - from tentative approaches at the beginning of relations to the acceptance of the presence of Aborigines on the garrisons, and with several Aboriginal people taking up regular residence in both garrison camps, with regular visits by others. The amicable relations between Aboriginal people and the personnel of these garrisons had everything to do with the short-term nature of these settlements, and at Raffles Bay the acquaintance of Aboriginal people with previous visits from Macassan trepangers. Particular circumstances explain the friendly relations at King George Sound: earlier attacks by sealers and enmity between Minong people and more northerly groups against which the presence of the garrison offered some protection.

Relations at Raffles Bay were marked by the constant exchange of gifts, some of which had the character of barter: a man gave a stone hatchet, basket and grasstree cord, demanding a steel hatchet in return (Mulvaney and Green 1992:113). There were exchanges of performances: local people sang and danced for the soldiers, and in turn witnessed a parade. Soldiers demonstrated shooting at a target; Aboriginal men demonstrated throwing spears. What Peterson (1993) has called 'demand sharing' was well in evidence. Barker describes how 
a man they called 'Waterloo' 'begged the pencil case from me, which I gave him' (Mulvaney and Green 1992:87). The demand side of demand sharing sometimes appeared excessive to Barker: a man called 'Wellington' by the British, Barker writes, 'bye and bye asks for everything he sees' (Mulvaney and Green 1992:90).

Conflict between the garrison and local men, as Barker describes it, centred not on land but on moveable property, and concerned 'theft' - a recurrent theme on the early frontier. A man named Luga, for example, made off with a garrison canoe at Raffles Bay and Barker had him whipped for it (Mulvaney and Green 1992:181). Those with whom relationships were established, however, recognised garrison property; a man called Mago, for example, borrowed a frying pan and pot from one Mrs Mills and on returning them 'would give them to nobody but her' (Mulvaney and Green 1992:113).

While he took pains to understand local Aboriginal people, and recorded names, vocabulary and customs, Barker does not reflect on Aboriginal concepts of property. Rather, he sees attitudes to the possessions of others as a matter of personal 'character' and 'trust'. Isaac Scott Nind, the surgeon under Barker's command at King George Sound in the south-west of Western Australia, does include remarks about property in his ethnographic sketch, published in the Journal of the Royal Geographical Society. Land is divided into districts, he remarks, and 'is the property of families or individuals' (Nind 1831:44). He has nothing to say, however, about personal possessions.

These remarks lead me to ask, what concepts of property did British colonisers bring to bear in their interpretations of Aboriginal actions and apparent attitudes and how did these understandings contrast with Aboriginal concepts and institutions of possession? The now familiar story is that according to colonial ideologies hunters and gatherers had no concepts of property, as they did not till the soil (Buchan 2001). Jurists such as Vattel provided legal justification for acquiring colonies by 'discovery' and 'settlement'; and the doctrine of terra nullius was applied to Australia-deemed to be a settled colony. A key legal case was the Gove case (Milirrpum 1971), in which Blackburn J. found both that communal native title was not recognised in the common law and that the relation between a Yolngu clan and its land was not a proprietary one, for it lacked diagnostic features, especially exclusive possession and the ability to alienate the land. The Blackburn judgment contrasts with that of Marshall in the United States (1823), which recognised Native American rights of occupation, and that of Chapman in New Zealand (1847). This ground has been well covered by writers such as Henry Reynolds (1987) and Nancy Williams (1986), although Reynolds (1987:136) found that there was a greater awareness and acceptance of 'native title' than previous accounts had suggested. 
I shall move away from these particular perspectives and examine, rather, the property concepts and assumptions brought to bear by individuals in their day-to-day encounters on the frontier and in their reflections on the nature of Aboriginal society. These are rather hard to get at, but discussions about changes in property concepts and property law through the early modern period in England are enlightening as to the background of such interpretations.

\section{Property concepts in late eighteenth-century England}

What seems to have taken place through the early modern period is the coming together of land and personal possessions under the rubric of 'property', with the commodification of land, the extension of the law of contract and widening of the scope of contract relations (Lieberman 1995:150, 155). In Blackstone's view, the then new 'commercial mode of property' set new legal requirements to 'facilitate exchange and alienation', so that although many aristocratic families held land in entail, land was becoming more readily alienable (Atkinson 1998; Lieberman 1995:148-9). Common rights in land continued and shared use rights such as the right to glean were widespread, but the enclosures movement reduced the importance of common rights in land (Atkinson 1998). The overarching category of 'property' had come to include all forms of commodities, of which the main subcategories were 'real' and 'moveable' property. The contrast between land and money as forms of property, seen also as a moral and psychological distinction, were entrenched in the early modern period (Klein 1995:222-3).

By the early twentieth century, property was no longer regarded in legal theory as 'absolute dominion', as in Blackstone's ideal, or as sui generis, but as a disaggregated 'bundle of rights'. The rights afforded by property were no longer absolutely distinguishable from those offered by other legal categories and no longer carried a clearly definable set of incidents (Davies and Naffine 2001:36). The modern understanding of property as 'disaggregated' is traced to the writings of Hohfeld in the early twentieth century (Hohfeld 1913, 1917; see also Gordon 1995:96), although scholars attribute the expression 'bundle of rights' to Maine (Hann 1998).

Given the fundamental distinctions between personal and real property, and between commerce and landed interests, how was Aboriginal 'property' understood through the nineteenth and early twentieth centuries? ${ }^{1}$

1 Atkinson (1998) points out the variety of forms of landownership in early colonial Australia. These included grants of 'common lands' by Governor King to various communities and Governor Macquarie's 


\section{The interpretation of Aboriginal 'property'}

\section{The 'no-property' view}

One opinion expressed in the late eighteenth and early nineteenth centuries was that Aborigines had no concept of property at all-in relation to either land or personal possessions. Governor Phillip's initial dispatches wrote of the Indigenous peoples as living in a 'state of nature', desiring 'little ornaments' but 'having no conception of ownership' (HRA:vol. 1, p. 145). 'Fidelis' in the Sydney Gazette of 1824 argued that the colony was not the 'property of its original inhabitants', who had 'no notion of property as applicable to territorial possessions', for people wandered 'wherever inclination prompted' (Reynolds 1987:167). The country was to be regarded as 'an unappropriated remnant of common property' (Reynolds 1987:168). The main justification was Lockean: it was 'the right and duty of civilization to occupy and subdue the soil' (North Australian 1861, cited in Reynolds 1987:171). ${ }^{2}$ Eyre quotes a letter in the South Australian Register of 1 August 1840:

It would be difficult to define what conceivable proprietary rights were ever enjoyed by the miserable savages of South Australia, who never cultivated an inch of soil, and whose idea of the value of its direct produce never extended beyond obtaining a sufficience of pieces of white chalk and red ochre wherewith to bedawb their bodies for their filthy corroborees. (Eyre 1845:vol. 2, pp. 296-7)

The familiar link is made here between the origin of property and agriculture. Eyre (1845:vol. 2, p. 296), however, argued strongly against the no-property view: 'It has generally been imagined, but with great injustice, as well as incorrectness, that the natives have no idea of property in land, or proprietary rights connected with it. Nothing can be further from the truth than this assumption.' The same unjust assumption is made in 'the public journals of the colonies' (Eyre 1845:vol. 2, p. 296).

The no-property view seems to have been a minority one, however, if Taplin's (1879) survey is a reliable indication. Three of Taplin's respondents replied to his question of whether the Aborigines had no property; one respondent was the principal of an institution, one a crown land ranger and one a police trooper.

grant of freehold land to Aboriginal people (Atkinson 1998:13). Property in land had a confused status, especially in the case of squatting, which burgeoned from the 1830s. Thus, land was not straightforwardly private property.

2 Reynolds (1987) notes the contradiction: that a very small proportion of Australia was brought under the plough. 
Eleven others described inheritance or in some cases destruction of personal possessions; most were police troopers, one was Gason the ethnographer of the Dieri, and one a telegraph station master.

In a contrary vein, a number of late eighteenth and early nineteenth-century commentators - both in Van Diemen's Land (Tasmania) and on the mainlandcommented on the strength of Aboriginal assertions of ownership of land. Collins (1798:598-9) thought that Aboriginal conceptions of property related not simply to objects of use, but 'strange as it may appear' to their 'real estates' held as a kind of 'hereditary property, which they retained undisturbed' (see also Buchan 2001:145). Bishop Broughton reported to a House of Commons Select Committee that the Aborigines had a 'conception of our having excluded them from what was their original property' (Reynolds 1987:139). G. F. Moore, a West Australian settler, described the delight of an Aboriginal man in his own country, as did the Tasmanian historian West (Reynolds 1987:139), who described a place on Flinders Island as 'a station of his [the Aboriginal man's] people'.

Barrington (1810) and Paterson (1811) draw on very similar material for their views on Aboriginal property, though Paterson's is the fuller account. Paterson comments, '[t]heir spears and shields, their clubs and lines, \&c., are their own property; they are manufactured by themselves, and are the whole of their personal estate' and echoes Collins' remark about possessing 'real estates' (Reynolds 1987:126-7). He reports Bennelong's assertion that Goat Island (Memel, in Sydney Harbour) was 'his own property' - it had been his father's and he would give it to By-gone, 'his particular friend and companion'-and his attachment to the place. Bennelong also spoke of others 'who possessed this kind of hereditary property, which they retained undisturbed' (by other Aboriginal groups presumably) (p. 127). Paterson thought women, however, to be 'the slaves of men' (Reynolds 1987:118). Drawing on Collins, Barrington (1810:24) adds canoes, hatchets and fish-gigs to the list of 'property', and notes that Bennelong took great pleasure in being on Goat Island with his wife.

Isaac Scott Nind writes (1831:44) of Minong people at King George Sound in the south-west of Western Australia that ' $[\mathrm{t}]$ hey are very jealous as to encroachments on their property, and the land is divided into districts, [each of] which is the property of families or individuals'. Except during seasons when people move away from their own country,

those natives who live together have the exclusive right of fishing or hunting upon the neighbouring grounds, which are in fact divided into individual properties; the quantity of land owned by each individual being considerable. Yet it is not so exclusively his, but others of his family have certain rights over it; so that it may be considered as partly 
belonging to the tribe. Thus all of them have a right to break down grass trees, kill bandicoots, lizards, and other animals, and dig up roots; but the presence of the owner of the ground is considered necessary when they fire the ground for game. (Nind 1831:28)

Thus for Nind, 'property' is equated with land. He applies a tribe/family/ individual model of relations to land, understands 'districts' to be owned by family groups or individuals and uses the language of 'rights' to grapple with the subtleties of use and control. Indeed, the 'tribe/district' model was common in early writings about Aboriginal property in land.

\section{Tribe, family and individual as property holders}

The most common interpretation of Aboriginal relations to land through the first half of the nineteenth century was cast in terms of tribe, family and individual. Some accorded 'property in land' to the tribe and some interpreted ownership as exclusive possession that was defended, although what was referred to as the 'district' or 'locality' of the tribe was frequently described as a place of residence rather than ownership. Phillip referred to tribes 'residing' in their particular districts rather than owning them, while John Hunter (1793:62) wrote of each 'tribe' having a locality or place 'where the tribe resides'.

Eyre (1845:vol. 2, p. 297) generalises that Aboriginal 'districts' were about 10 to 20 miles $(16-32 \mathrm{~km})$ in radius, 'being the property and hunting grounds of the tribes who frequent them', and 'parcelled out' among individual members, such that '[e]very male has some portion of land, of which he can always point out the exact boundaries' (this passage is ambiguous; does it mean that men of a group had individual connections to particular portions of land or that males had joint rights?). A 'tribe' could enter another tribe's district only with the permission or invitation of that tribe (Eyre 1845:vol. 2, 297). Eyre thought that a father subdivided his property during his lifetime and that properties 'descend in almost hereditary succession', although females, he thought, did not inherit (Eyre 1845:vol. 2, p. 297). Eyre does not describe personal property; the issue was property as land, seen as belonging to the individual and the tribe, the boundaries defended, and as entailing rights in animals on the land, and indirectly the grass.

Eyre cites Grey (1841), who thought that 'landed property' belonged to individual males, each of whom accurately knew the 'limits of his property' and that 'various objects' marked the boundary (Eyre 1845:298, citing Grey 1841:232). The Grey extract cites a letter from Lang to one Dr Hodgkin, affirming that Aborigines had an idea of 'property in land'. Every 'tribe' has its own 'district', with boundaries well known 'to the natives generally'. Within a district all wild animals 'are considered as much the property of the tribe inhabiting, or rather 
ranging on, its whole extent, as the flocks of sheep and herds of cattle...are held by European law and usage the property of their respective owners' (Eyre 1845:298). People of a particular tribe 'regard the intrusion of any other tribe of Aborigines upon that district, for the purposes of kangaroo hunting, \&c, as an intrusion, to be resisted and punished by force of arms' (Eyre 1845:299).

Lang thought that within tribal territories, 'particular sections or portions of these districts are universally recognised by the natives as the property of individual members of these tribes' (Eyre 1845:299), and he describes how an owner might invite tribes from other districts as well as his own to participate in burning off the country. The Reverend W. Yates testified to a House of Commons Select Committee (which reported in 1836 and 1837) as to the relation of a 'tribe' to a 'district' as 'their own property'.

Salvado (1977) gives a picture of each 'family' owning a 'district' such that each individual member had a distinct foraging territory (he is referring to the New Norcia district in the south-west of Western Australia). The heading to Salvado's Chapter 17 includes 'Proprietary rights over terrain'. The entry is brief, but he describes exclusive possession:

Every individual has his own territory for hunting, gathering gum and picking up yams, and the rights he has here are respected as sacred. I have often heard them say in dispute - even to their friends: 'Nichia n-agna cala, nunda cala Canturbi; iei nunda uoto' ('This is my district, yours is Canturbi [the name of a place near New Norcia]; get out of here straightaway!'). Consequently, each family regards one particular district as belonging exclusively to itself, though the use of it is freely shared by nearby friendly families. But if an enemy or a stranger is caught there, he is put to death by the owner. (Salvado 1977:181)

Several early sources use the language of 'rights' to describe Aboriginal relations to land. Salvado's use of the expression 'proprietary rights' has already been noted. Governor Gawler of South Australia and Charles Sturt, then Land Commissioner, argued that Aborigines had 'natural indefeasible rights invested in them as their birthright'. Before settlement, they 'possessed well understood and distinct proprietary rights over the whole of the available lands in the Province' (Reynolds 1987:147). In a similar vein, L. E. Threlkeld wrote of Aborigines' 'rights of birth' (Reynolds 1987:150). Nind (1831), the assistant surgeon at King George Sound, described varieties of 'rights', including the exclusive rights of a residence group to use 'neighbouring grounds'.

Early commentators categorise personal possessions as property. Governor Phillip 'seemed willing to protect those articles of use and possession such as spears and "fiz-gigs" [harpoons] that the settlers invariably stole whenever they 
found them unattended' (Buchan 2001:145). Most of Taplin's correspondents in Victoria who responded to the question about property a little later in the century described the inheritance of personal items by close relatives. Early accounts also describe exchange, under the headings of 'trade' and 'barter' (Taplin 1879). Captain Barker had made observations of gift giving at King George Sound (Mulvaney and Green 1992). Ethel Hassell (1936) and Daisy Bates (1985) describe exchange in the south-west of Western Australia; items included spear shafts from the mulga country, stone flakes, throwing sticks and various foods.

\section{The terms in which Aboriginal 'property' is described}

What, then, are the terms in which Aboriginal owning is described by such commentators? To sum up, we find the following:

- concepts of 'owner' and 'property', 'landed property' and 'property in land'

- property described in terms of the possession of rights: proprietary rights, exclusive rights, 'natural indefeasible rights' and birthright

- conceptions of tribes and families as occupiers of land or holders of property

- territories and 'sections' or 'portions' of territories associated with such groups and with individuals, described as places of residence or use, or as property or 'real estates', and in one case, 'station'

- both land and personal possessions, where recognised, are seen as inherited or passed down by 'descent' or 'hereditary succession'

- exchange is described in terms of 'trade' and 'barter'.

\section{Amateur anthropologists' accounts of Aboriginal property}

Among interested amateur anthropologists of the latter part of the nineteenth century, Taplin (1879) was a missionary of the Ngarrindjerri of the River Murray mouth in South Australia and Howitt $(1880,1904)$ was a magistrate, Protector of Aborigines and farmer who employed Kǔrnai people on his hop farm in Gippsland, eastern Victoria. Both circulated questionnaires to property owners, police, protectors, and so on. Others such as Ethel Hassell (1936) (the wife of a property owner in the south-west) and Dawson (1881) (a property owner in western Victoria), as well as Howitt, wrote ethnographic notes on particular peoples with whom they had economic relations. (Others included Gideon S. Lang [1865]; Curr [1886-87]; Spencer and Gillen [1938]; and Horne and Aiston [1924].) 
Lang (1865:5) writes that:

Every tribe occupies its own territory, which is as distinctly defined as any estate in England, and is on no account encroached upon by any stranger, unless upon pain of death...This tribal right to exclusive occupation is, however, modified in certain cases for the benefit of the tribes generally.

He reports access by others for particular kinds of food and raw materials: 'these are general laws giving all the tribes authority to resort to the place without offence either to the tribe permanently located there, or to those through whose country it is necessary to pass in order to reach it' (Lang 1865:5-6).

Tribal land also 'belongs to different members of families of the tribe; it is always jealously watched, and transmitted from generation to generation' (Lang 1865:13). Lang also describes 'personal right of property' in trees and resources found in trees, citing the same sources as Smyth (Lang 1865:13; Smyth 1878).

Curr (1886-87:vol. I, p. 42) thought that for Aboriginal people, '[a]t present, the accumulation of property, or even the care of it, seems to him not worth the trouble it costs'. Curr compares the freedom of the individual in English and Aboriginal societies:

Thus, civilization aims at restricting governmental interference to property, and as far as possible leaving the person untouched. In savage life in Australia, on the contrary, there is no interference with property; with the net, shield, and spear a man has made, and the food he has obtained, he may do as he chooses, but no individual, male or female, passes through life without many interferences with his or her person. (Curr 1886-87:vol. I, p. 51; emphasis in original)

Curr had in mind here bodily mutilation associated with initiation, mourning, and so on. He thought Taplin wrong in saying that among the Ngarrindjerri ('Narrinyeri') property such as weapons, implements and ornaments belonged to the tribe in common; rather, 'such things are personal property' (Curr 188687:vol. I, p. 66): 'the rights of personal property are as much regarded within the tribes as amongst ourselves.'

Concerning land, Curr (1886-87:61) writes that tribes 'occupy practically in common, and to the exclusion of all others, a tract of country which they claim as their own'. Tribes within 'associations' of tribes 'are always distinct; their lands are not held in common' (Curr 1886-87:63), but each tribe's land is divided into portions with known though imprecise boundaries, not artificially marked, and 'each of which is the personal property of a single male'. People had 'a very elaborate nomenclature for their lands' (Curr 1886-87:64). Curr (p. 64) thought 
that a father would divide his lands among his sons before he died, letting the tribe know what he had done, although the sons did not inherit the land until after his death, but females did not inherit, he thought. In the absence of sons, the land would go to the nearest male relative. He writes that 'prior to the coming of the Whites each tribe held its territory, when necessary, vi et armis, against all intruders' (p. 69). Curr thought that 'the wife is the property of the husband', but he allowed her 'undisputed possession of the bags, ornaments, \&c., which she may make or acquire; so that I have often seen a woman give such things away, and have heard husbands ask permission of their wives to take something out of their bags' (p. 66).

Foelsche (1895) also subscribed to the tribe model: 'Each tribe has a recognised land boundary', he writes,

which is always sacredly respected, and each family or clan in the tribe have their particular portion of land within this boundary. I have never heard of any quarrelling or disputes over boundaries. All families or clans camp promiscuously together anywhere they choose within the tribal boundary. (Foelsche 1895:195)

Like Howitt $(1880,1904)$, Taplin (1879) thought that tribes (defined by common language and common customs) were divided into exogamous 'clans', each with its own name and symbol and with an ideology of common descent. He depicts the clan as highly corporate; even a man's property rights in his implements and weapons were 'subject to the superior rights of his clan' (Taplin 1879:11).

Writing about Aboriginal people of the Western District of Victoria, Dawson (1881) uses a stronger language of property, including terms such as 'rights', 'inheritance', 'owner', 'landed property' and 'estate'. Property for Dawson was just 'land'; he does not include personal possessions. He writes of the 'territory belonging to a tribe' being 'divided among its members':

Each family has the exclusive right by inheritance to a part of the tribal lands, which is named after its owner; and his family and every child born on it must be named after something on the property.

When the father of a family dies, his landed property is divided equally among his widow and his children of both sexes. Should a child of another family have been born on the estate, it is looked upon as one of the family, and it has an equal right with them to a share of the land, if it has attained the age of six months at the death of the proprietor. (Dawson 1881:7)

Moving to the early twentieth century, A. W. Howitt (1904) rarely uses the term 'property' and it does not appear in the index of his comparative study 
of Aboriginal peoples of south-eastern Australia. Rather, he writes of 'tribal organisation' and 'local organisation' contrasted with 'social organisation'. A 'tribe' is associated with a 'locality'; divisions of the tribe are 'local' and are 'geographical divisions' (Howitt 1904:42-4, 71). He writes of a tribe as 'occupying' country or being of 'their country' and of Wiradjuri 'boundaries' (central New South Wales) or country 'inhabited' by a tribe (Howitt 1904:49, 54-7). In the case of the Kǔrnai 'tribe' (eastern Victoria), clans were divided and subdivided, 'each subdivision having its own tract of hunting and food ground' (Howitt 1904:73). He names 'divisions' according to a place or locality, briefly defined (pp. 76-7), and writes of 'the country of the Brabralung' clan (p. 73). The Bunjil-baul division claimed Raymond Island in the Gippsland Lakes and the swans' eggs laid on it 'as their exclusive property' (Howitt 1904:73).

Spencer and Gillen (1968:590) mention property only once; they report that among the Arrernte (Arunta) of Central Australia, the pebbles for a type of hatchet were obtained from particular localities 'which were the property of local groups of men without the permission of whom the stone could not be removed', and note that A. W. Howitt (1880:232) reports similar ownership of quarries in Victoria.

'Of property, as such,' write Horne and Aiston (1924:33) of the Wangkangurru ('Wongkonguru') people of the Simpson Desert, 'there is but little definite trace'. A person's personal possessions 'are respected absolutely', however, for it 'is not considered right or proper to use anything that has belonged to another man' (Horne and Aiston 1924:33). A weapon or implement may lie in the fork of a tree or on the ground and not be touched - neither would a store of seeds (Horne and Aiston 1924:33). They describe trade and barter for locally made implements (p. 34). What they refer to as 'tribal possession' among Blinman people, who were a 'subdivision' of the Kuyani ('Kooyiannie') people (Lake Torrens, South Australia), included ochre deposits. Others would send a message stick to obtain permission to mine the ochre: 'Until the whites came the tribal boundaries were religiously kept, and it is sufficient for them that these are their lands and have been for generations' (Horne and Aiston 1924:35). Horne and Aiston (1924:35) recount traditions that Wangkangurru formerly lived where Ngamini ('Ngameni') people now dwell (Simpson Desert), however, they were pushed south by them, displacing the Diyari ('Dieri'), who moved further south. Aiston was a policeman and chief protector in the region.

Thus, the 'tribe/district' model of relations to land persists in these authors' works, although Taplin and Howitt recognise another layer of relations of people to country: the clan, and (in Howitt's case) its subdivisions. To sum up the property concepts deployed in these writings: 
- concepts of property, 'exclusive property' and 'rights' persist: the 'right to exclusive occupation' of a territory on the part of a tribe, the exclusive right of a family to a part of the tribal land (Dawson), land and swan eggs as the 'exclusive property' of a particular division of a 'clan' (Howitt) and quarries controlled as the property of a local group (Howitt, Spencer and Gillen)

- conceptions of tribes and families also persist, augmented by 'clan' and divisions and subdivisions of the clan in Howitt's model, and in Spencer and Gillen, 'local groups of men' who own quarries

- the land of a tribe and clan is described in terms of territories, estates (Lang, Dawson) and 'country' (Lang), and as 'portions' (Curr) or 'parts' (Dawson) of tribal land, and the 'locality' of a tribe or division (Howitt)

- once again, land is seen as inherited or 'transmitted' from generation to generation (Lang)

- Lang and Smyth add individual rights to trees or resources within trees

- Curr was alone in thinking that a woman was the property of her husband

- Taplin thought members of a clan had 'common rights' in weapons and implements, though others depicted such items as personal property.

\section{Early professional anthropologists' accounts}

Turning to trained anthropologists of the early twentieth century, RadcliffeBrown built on the tribe/clan/family model. In his 1913 and 1918 articles, he uses the term 'local group' rather than clan, and in his 1918 notes on Australian tribes, he writes of 'the territory and its products' as 'belonging to' each local group. He introduces the term 'horde' to denote a group of people who lived together, complementing 'clan' as a descent group. A person required the permission of other groups to hunt (and presumably gather) on their country, unless following game. 'Acts of trespass', he thought, were punishable by death (Radcliffe-Brown 1913:146). A local group is, however, clan-like in this model, for he writes that each child belongs to the local group of its father (RadcliffeBrown 1913:145, 146). His account of the relationship between clan and horde varies; the Yaralde 'clan-horde' (River Murray mouth) consisted of 'persons who regarded themselves as being closely related in the male line' (Radcliffe-Brown 1918:228) and the group included wives and unmarried children (p. 231). In his later overview, he writes of the horde (rather than the clan) as possessing proprietary rights over the land and its products (Radcliffe-Brown 1931).

W. Lloyd Warner (1937) was the first to carry out long-term fieldwork with an Aboriginal community (this was in the late 1920s): Yolngu or 'Murngin' of north-east Arnhem Land in the Northern Territory. He was also perhaps the first of the major ethnographers to question the 'property' analysis of Aboriginal 
land, and he extends the concept of property to include 'incorporeal property' such as ritual. He distinguishes three 'types' of property: items of technology, land and incorporeal property such as names and totemic designs.

It is the Yolngu ('Murngin') 'clan' rather than the residence group that owns land and other property in his account. Land is divided among the clans, he writes, 'and definite areas and their natural objects such as trees, water holes, and the like are considered as belonging to these exogamic units' (Warner 1937:146). The moieties are also supposed to have an 'owning' relationship to these areas of land, by derivation (Warner 1937:140). The ownership of land includes the use of it, but members of other clans are not excluded from its use, but in the case of two friendly groups, encouraged (Warner 1937:147). Items of technology are 'personally owned', although a number of fathers, sons and brothers who have cooperated in an enterprise such as building a boat 'have a feeling of collective ownership' (Warner 1937:147).

Among elements of incorporeal property, the concept of which he saw as 'not very highly developed' (Warner 1937:147; cf. Keen 1994), were a man's name, 'which is his own', although others may share it, and totemic designs associated with clans and moieties: 'it would be impossible for members of the other clans or moiety to use these designs or emblems unless given permission under special circumstances.' Totemic designs, like totems themselves and rituals, 'are not so much properties in an economic sense as integral parts of the structure of the clan'; moreover, '[t]o a great extent this is also true of the land' (Warner 1937:147). They belong to 'an economic category' only in a secondary and derivative sense, 'yet the effect of their being part of the clan and moiety configuration has many of the attributes of our concept of property' (Warner 1937:147). No songs or painted designs are considered the property of any one individual or group, Warner thought (incorrectly) (p. 147; cf. Keen 1994; Morphy 1991). The ritual belonging to a healer ('medicine man', marrngitj) is not so much owned as acquired through inherent ability in combination with a mystical experience (Warner 1937:148).

Warner (1937:147-8) thought the Yolngu sense of property to be 'undeveloped', as the result of their 'lack of interest in developing their technological equipment', ultimately as a result of the need for mobility and hence portability. He qualifies the use of the expression 'property'. Land, the natural features on it and 'incorporeal property' including ritual and totemic designs, he writes, were less the 'property' of the clan and more an integral 'part' of it (Warner 1937:146-9). This reflects Yolngu distinctions rather more closely than does the property model.

Donald Thomson (1972), who carried out fieldwork in eastern Cape York Peninsula in the late 1920s, describes subtleties of property relations among 
particular categories of relative. Young men could use the possessions of those with whom relations were unconstrained without asking permission; these included his close father's father, mother's father and mother's older brother. Among Umpila speakers, a poladu (SS) could borrow his pola's (FF's) spears and other possessions without asking him: 'He looks [sees] but he doesn't talk [say anything]' (Thomson 1972:11); and similarly 'a person may use the spear or canoe of his ngatjimo [MF/FMB] without having to ask permission' (p. 11). Such freedom was also customary between a man's younger sister's child and his mother's older brother, but not his mother's younger brother, with whom relations were reserved (Thomson 1972:12). It is implicit in Thomson's account that one should ask other relatives' permission before using their possessions.

To sum up the views of these professional anthropologists:

- concepts of property and 'proprietary' rights again persist, with a local group, horde or clan having proprietary rights over its territory and products, together with attendant concepts of trespass and permission (Radcliffe-Brown)

- there are qualifications from Warner: land 'belongs to' the clan, but is a part of it rather than being its property, as are songs and totemic designs (Warner)

- ideas about personal property persist, although more subtly described by Thomson.

\section{The grid of English categories of property}

The overall picture seems to be, then, that commentators interpreted Aboriginal possessions not only in terms of the all-encompassing concept of 'property', including personal possessions, land, wives (in one view) and 'incorporeal' things, but also projecting English social structure onto Aboriginal social relations. The tribe is the equivalent of the nation, with its common language, territory (which the tribe defends) and body of custom. It is divided into family groups, each with an 'estate'. In several accounts, individuals inherit property in land from the father post mortem and pass it down to sons or to other close relatives in the absence of sons. The 'family' is thus constituted as a succession of individual landholders - reminiscent of aristocratic families holding land in entail. Radcliffe-Brown's 'horde' with its property in land is in effect an expanded family. Certain class elements are read into Aboriginal social relations in interpretations of prominent individuals as 'chiefs' (for example, Dawson 1881). (The later 'clan' model introduces an element with a Scottish but not an English equivalent.)

While both personal and real property are said to be held exclusively - especially land at the level of tribe - they are not described in terms of commodities. The 
language of commodities creeps in, however, when it comes to the exchange of moveable items, described as 'trade' or 'barter'. After all, 'trade' was a synonym for 'commerce' in eighteenth-century England and contrasted with the landed interest.

Thus, Aboriginal society - at least in its dimension of 'property' - is depicted through the nineteenth and early twentieth centuries as a primitive form of English society. Terms such as 'tribe' (from Latin tribus) and (later) 'clan' (adopted into Gaelic from Latin planta) give the structure its exotic, primitive character - 'tribe' used initially to label elements of Hebrew society and clan to denote Scottish kin groups. It is only when we come to Warner (1937) that 'property' begins to be qualified and the possessions of 'clans' are given a special status, more closely reflecting the kinds of distinctions made by Aboriginal people themselves.

\section{Kinds of Aboriginal 'property'}

How does present anthropological understanding of things 'owned' in Aboriginal societies of the kinds encountered in the early nineteenth century accord with these early colonial views? To generalise, in contrast with the allencompassing meta-category of 'property', things owned are divided into two broad domains.

First, the holding of land and waters ('country') and related sacred things including songs, designs, rituals and sacred objects is conceptualised in terms of connections to totemic ancestors who left traces in land and waters, and of kin relations to ancestors and among owners. Anthropologists have described such connections as implying intrinsic connections (Myers 1991:55), as inalienable or 'inclusive' (Hann 1998; Keen 2004:352-3) or in terms of 'consubstantial' connections (Bagshaw 1998). Kin relations permit degrees of connection to places - described in the anthropological literature in terms of kinds and degrees of 'rights' (for example, Williams 1986). Myers (1991:55) writes of a dialectic between autonomy residing in the right to be asked and relatedness in the tendency to include and share with others.

Second, ownership of moveable and consumable items is not thought of as inalienable, but is subject to demand sharing (Peterson 1993) (see also Chapter 5 this volume on trade and exchange), although people recognise the personal ownership of equipment. Ownership of larger items such as canoes (Thomson 1934) or more recently motor vehicles is strongly asserted, although regarded as belonging to a kin group more than an individual. With some exceptions, material culture items are excluded from the ancestral domain. Contract relations apply very widely to marriage in Aboriginal societies, which also links 
to the exchange nexus (Keen 2004:204-5). (This explains, perhaps, why some Europeans saw wives as chattels, for the relationship was read as a commodity relation.) In at least some Aboriginal societies, people are able to link personal possessions to the ancestral domain - reserving an item to personal or kin group use by, for example, painting a totemic design on the object (Keen 2004:301; Thomson 1939a). Items from the ancestral domain enter the nexus of gift exchange, including gifts in exchange for wives. ${ }^{3}$

Thus, in strong contrast with the assimilation of all kinds of things 'owned' to 'property' in British and similar cultures, 'country', associated rituals, and so on are treated very differently from personal possessions (and marriage) in Aboriginal ones. Are there equivalents, however, to 'owner' and 'property' in Aboriginal languages? The closest to 'owner', perhaps, are suffixes such as -waltja in Western Desert languages (Myers 1986:55) and -watangu in Yolngu dialects (Keen 1994), but the second of these at least has a more restricted range of application than 'owner' and connotes what linguists call inalienable possession (part-whole and kin relations). There is no equivalent to the overarching concept of property.

\section{Concluding remarks}

The results of this brief exercise have been somewhat surprising. Commentators drawing on their experience on the colonial frontier (as well as the experiences of others) interpreted Aboriginal 'property' relations as simulacra of English property relations, albeit gradually modified with systematic research. One might have expected a more exotic, 'savage' society to be constructed, consonant with the depiction of 'superstitions' and 'magic'.

Can it be said that the interpretation of Aboriginal ownership shaped relations on the frontier? Much more important factors seem to have included economic and political interests and particular circumstances. The interpretation of Aboriginal 'property' relations has, however, been significant at the wider legal and political levels, as in the Gove Case, the Aboriginal Land Rights (Northern Territory) Act and native title. It is here that their main impact lies.

In the Gove case (Milirrpum 1971), Justice Blackburn rejected the property model, for it appeared inconsistent with the Yolngu evidence (Williams 1986). Clans did not seem to hold land to the exclusion of others and it was not alienable. It is significant that in recognising the existence of native title at

3 There is a parallel on the north-west coast of North America. Among Gitksan people, for example (Cove 1982), the holding of land and waters is conceived of in terms of a group's sharing a spirit essence with the land and its creatures - extended to the group's crest, stories and songs. 
common law in Mabo II, the High Court avoided the term 'property', preferring to treat native title as a sui generis form of title, and wrote rather of 'connection' to land (Bartlett 1993), avoiding the difficulties faced in the Gove case, although 'title' embeds the concept of property. Six of the seven judges declared that the content and nature of common-law native title are determined according to the traditional laws and customs of the Indigenous people who, according to these laws and customs, have a 'connexion with the land' (Howe 1995:5). Justices Dean and Gaudron suggested that it is preferable 'to recognise the inappropriateness of forcing the native title to conform to traditional common law concepts and to accept it as sui generis or unique' (Howe 1995:6). In order for native title rights to be enforced at common law, the High Court found it necessary to equate them to some degree to common-law concepts of property rights, although the court could not reach a consensus on whether these rights were proprietary or personal (Howe 1995:6). In spite of the view that native title has a sui generis character, there has been a consistent push in native title litigation to treat Aboriginal ownership of land and waters in terms of divisible 'incidents' of title.

What are the implications of the ideas about the character of Aboriginal property reviewed in this chapter for ideas about Aboriginal economy as a whole? Apart from subsistence techniques and technology, and to an extent exchange, property was the main aspect of economy that early commentators addressed; Aboriginal people were not thought of as having 'economies', perhaps because economy was defined mainly through the flow of money. Anthropologists of the mid-twentieth century began to model Aboriginal ecologies (for example, Thomson 1939b), but only later in the century were Indigenous economies discussed, together with the place of Aboriginal people in the Australian economy (for example, Young 1981).

Anthropologists like to think that they are rather less ethnocentric than their nineteenth-century forebears in their depictions of cultures different from their own. When it comes to the study of 'property' cross-culturally, however, by far the most common framework for doing so is in terms of 'rights', 'obligations' and 'duties', in spite of the very particular role of these terms in British and related legal systems (for example, Hann 1998; von Benda-Beckmann and von Benda-Beckmann 1999). Strathern (1984) has been one of the very few to question the application of the concept of 'property' - in relation specifically to the Highlands of Papua New Guinea. If an anthropologist writes that Yolngu recognise a 'right to do $\mathrm{x}^{\prime}$ ', how is it expressed? Is 'right' an apt translation? Anthropologists need to record and interpret more of the Indigenous discourse about 'owning' things. 
Indigenous Participation in Australian Economies

\section{Bibliography}

Atkinson, A. 1998, 'The British legacy: land disposal and use in early colonial Australia', in R. Morton (ed.), The Land and the People: The Wik lectures, The History Institute, Carlton, Vic.

Bagshaw, G. 1998, 'Gapu dhulway, gapu maramba: conceptualisation and ownership of saltwater among the Burarra and Yan-nhangu peoples of northeast Arnhem Land', in N. Peterson and B. Rigsby (eds), Customary Marine Tenure in Australia, University of Sydney, NSW, pp. 154-77.

Barrington, G. 1810, The History of New South Wales..., M. Jones and Sherwood, Neely and Jones, London.

Bartlett, R. 1993, 'The Mabo decision', Australian Property Law Journal, vol. 1, no. 3, pp. 236-61.

Bates, D. 1985, The Native Tribes of Western Australia, National Library of Australia, Canberra.

Brewer, J. and Staves, S. 1995, Early Modern Conceptions of Property, Routledge, London and New York.

Buchan, B. 2001, 'Subjecting the natives: Aborigines, property and possession under early colonial rule', Social Analysis, vol. 45, no. 2, pp. 143-62.

Collins, D. 1798, An Account of the English Colony in New South Wales, with Remarks on the Dispositions, Customs, Manners, \&c. of the Native Inhabitants of that Country[...], T. Cadell Jr and W. Davies, London.

Cove, J. J. 1982, 'The Gitksan traditional concept for land ownership', Anthropologica, vol. 24, no. 1, pp. 3-17.

Curr, E. M. 1886-87, The Australian Race, [2 vols], John Ferres, Government Printer, Melbourne.

Davies, M. and Naffine, Ng 2001, Are Persons Property? Legal debates about property and persons, Ashgate, Aldershot, UK.

Dawson, J. 1881, Australian Aborigines: The languages and customs of several tribes of Aborigines in the Western District of Victoria, Australia, George Robertson, Melbourne.

Eyre, E. J. 1845, Journal of Expeditions of Discovery into Central Australia..., T. and W. Boons, London. 
Foelsche, P. 1895, 'On the manners, customs, religions, superstitions of natives of Port Darwin and west coast of Gulf of Carpentaria', Journal of the Royal Anthropological Institute, vol. 24, pp. 190-8.

Gordon, R. 1995, 'Paradoxical property', in J. Brewer and S. Staves (eds), Early Modern Conceptions of Property, Routledge, London and New York, pp. 95110.

Grey, G. 1841, Journals of Two Expeditions of Discovery in North-west and Western Australia, During the Years 1837, 38 and 39, Volume 2, Boone, London.

Hassell, E. 1936, 'Notes on the ethnology of the Wheelman tribe of south Western Australia', Anthropos, vol. 31, pp. 679-711.

Hann, C. M. 1998, 'The embeddedness of property', in C. M. Hann (ed.), Property Relations: Renewing the anthropological tradition, Cambridge University Press, UK, pp. 1-47.

Historical Records of Australia (HRA), vol. 1, series 1, p. 14.

Hohfeld, W. N. 1913, 'Some fundamental legal conceptions as applied in judicial reasoning', Yale Law Journal, vol. 23, pp. 16-59.

Hohfeld, W. N. 1917, 'Fundamental legal conceptions as applied in judicial reasoning', Yale Law Journal, vol. 26, pp. 710-70.

Horne, G. and Aiston, G. 1924, Savage Life in Central Australia, Macmillan and Co., London.

Howe, A. 1995, 'A poststructuralist consideration of property as thin airMabo, a case study', E Law: Murdock University Electronic Journal of Law, vol. 2, no. 1, <http://www.murdoch.edu.au/elaw/issues/v2nl/how21.html>

Howitt, A. W. 1880, 'The Kǔrnai tribe: their customs in peace and war', in L. Fison and A. W. Howitt (eds), Kamilaroi and Kǔrnai: Group-marriage and relationship, and marriage by elopement, George Robertson, Melbourne, pp. 177-260.

Howitt, A. W. 1904, The Native Tribes of South-East Australia, Macmillan, London.

Hunter, J. 1793, An Historical Journal of the Transactions at Port Jackson, Printed for J. Stockdale, London.

Keen, I. 1994, Knowledge and Secrecy in an Aboriginal Religion, Clarendon Press, Oxford. 
Indigenous Participation in Australian Economies

Keen, I. 2004, Aboriginal Economy and Society: Australia at the threshold of colonisation. Oxford University Press, Melbourne.

Klein, L. E. 1995, 'Property and politeness in the early eighteenth-century Whig moralists', in J. Brewer and S. Staves (eds), Early Modern Conceptions of Property, Routledge, London and New York, pp. 234-53.

Lang, G. S. 1865, The Aborigines of Australia, Wilson and Mackinnon, Melbourne.

Lieberman, D. 1995, 'Property, commerce, and the common law: attitudes to legal change in the eighteenth century', in J. Brewer and S. Staves (eds), Early Modern Conceptions of Property, Routledge, London and New York, pp. $141-58$.

Milirrpum 1971, [Judgment in the] Supreme Court of [the] Northern Territory [between] Milirrpum $v$ Nabalco Pty Ltd and the Commonwealth of Australia (Gove Land Rights Case), Law Book Company, Sydney.

Morphy, H. 1991, Ancestral Connections: Art and an Aboriginal system of knowledge, University of Chicago Press, Ill.

Mulvaney, J. and Green, N. 1992, Commandant of Solitude: The journals of Captain Collet Barker 1828-1831, Melbourne University Press at the Miegunyah Press, Carlton.

Myers, F. 1986, Pintupi Country, Pintupi Self, Australian Institute of Aboriginal Studies, Canberra.

Myers, F. 1991, 'Burning the truck and holding the country: property, time and the negotiation of identity among Pintupi Aborigines', in T. Ingold, D. Riches and J. Woodburn (eds), Hunters and Gatherers: Property, power and ideology, Berg, Oxford, pp. 52-73.

Nind, I. Scott 1831, 'Description of the natives of King George's sound (Swan River Colony) and adjoining country', Journal of the Royal Geographical Society of London, vol. 1, pp. 21-51.

Paterson, G. 1811, The History of New South Wales from its First Discovery to the Present Time..., Mackenzie and Dent, Newcastle upon Tyne.

Peterson, N. 1993, 'Demand sharing: reciprocity and the pressure for generosity among foragers', American Anthropologist, vol. 95, no. 4, pp. 860-74.

Radcliffe-Brown, A. R. 1913, 'Three tribes of Western Australia', Journal of the Royal Anthropological Institute, vol. 43, pp. 143-94.

Radcliffe-Brown, A. R. 1918, 'Notes on the social organization of Australian tribes', Journal of the Royal Anthropological Institute, vol. 48, pp. 222-53. 
Radcliffe-Brown, A. R. 1931, The Social Organization of Australian Tribes (Oceania Monographs No. 1), University of Sydney, Sydney.

Reynolds, H. 1987, Frontier: Aborigines, settlers and land, Allen \& Unwin, Sydney.

Salvado, R. 1977 [1853], The Salvado Memoirs, Edited and translated by E. J. Stormon, University of Western Australia Press, Perth.

Smyth, R. B. 1878, The Aborigines of Victoria..., J. Curry O'Neill, Melbourne.

Spencer, B. and Gillen, F. 1938 [1899], Native Tribes of Central Australia, Macmillan, London.

Strathern, M. 1984, 'Subject or object? Women and the circulation of valuables in Highlands New Guinea', in R. Hirschon (ed.), Women and Property, Women as Property, Croom Helm, London, pp. 158-75.

Taplin, G. (ed.) 1879, The Folklore, Manners, Customs, and Languages of the South Australian Aborigines, E. Spiller, Acting Government Printer, Adelaide.

Thomson, D. F. 1934, 'The dugong hunters of Cape York', Journal of the Royal Anthropological Institute, vol. 64, pp. 237-63.

Thomson, D. F. 1939a, 'Notes on the smoking pipes of north Queensland and the Northern Territory of Australia', Man, vol. 39 (June), pp. 81-91.

Thomson, D. F. 1939b, 'The seasonal factor in human culture, illustrated from the life of a contemporary nomadic group', Proceedings of the Prehistoric Society, vol. 5, pp. 209-21.

Thomson, D. F. 1972 [1950], Kinship and Behaviour in North Queensland, Australian Institute of Aboriginal Studies, Canberra.

Warner, W. L. 1937, A Black Civilization: A social study of an Australian tribe, Harper and Brothers, New York and London.

von Benda-Beckmann, K. and von Benda-Beckmann, V. 1999, 'Introduction', in Toon van Meijl and Franz von Benda-Beckmann (eds), Property Rights and Economic Development: Land and natural resources in Southeast Asia and Oceania, Kegan Paul International, London.

Williams, N. M. 1986, The Yolngu and their Land: A system of land tenure and the fight for its recognition, Australian Institute of Aboriginal Studies, Canberra.

Young, E. A. 1981, Tribal Communities in Rural Areas, [Aboriginal Component in the Australian Economy 1], The Australian National University, Canberra. 